\title{
A PROUSTI IDŐÉLMÉNY PSZICHODINAMIKAI ELEMZÉSE
}

\section{PINTÉR FERENC}

Budapest Főváros Önkormányzatának Gyermekotthona E-mail:scotch@izabell.elte.hu

\begin{abstract}
Dolgozatunkban különböző pszichológiai gondolatrendszerek keretében próbáltuk meg értelmezni a prousti önkéntelen emlékezés pillanataihoz kapcsolódó jellegzetes idóélményt, melynek során a fáradtság vagy rossz közérzet nyomasztó állapotában egy apró, jelentéktelennek tünő érzékletes inger hatására váratlanul újra megjelenik egy régi élmény, megdöbbentö élességgel, túláradó örömérzet kiséretében. Proust olyan kiváltságos pillanatokhoz vélt jutni az önkéntelen emlékezés által, melyekben a múlt tapasztalatai a tudatos én és a tudatos emlékezet szelektáló és torzító hatásait megkerülve tárulnak fel. Ezáltal az önkéntelen emlékezet a dolgok valódi, állandó természetét mutatja meg. Kohut értelmezésében a prousti idoélmény, melyben az elbeszélö szinte egy időben él át két, időben nyilvánvalóan távol eső pillanatot, azért jelentös, mert bizonyítékot szolgáltat az irónak folytonos, történetiséggel bíró pszichológiai létezéséröl, s ezáltal ingatag selfjének koherenciáját erösíti. Sands szerint Proust éppenhogy egy töredékes, ámde szélsőségesen pozitív self-érzést próbál visszanyerni, mely az idealizált anyával való szimbiotikus kapcsolathoz tartozik, s az anya halála után csak az önkéntelen emlékezés révén élhetó újra. Chankin a híres madeleine-epizódból kiindulva az önkéntelen emlékezést, s a belöle eredö asszociációfüzéreket, a traumatikus gyermekkort elrejtö fedöemlékek feloldási kisérleteként értelmezi, mely az iró azon alapvetőbb törekvésébe ágyazódik, hogy múltja igazságainak felkutatásával megszilárdítsa identitását. Magunk próbálkoztunk meg a prousti idóélmény Melanie Klein elmélete alapján történó elemzésével. Ebben a keretben az önkéntelen emlékezést olyan átmeneti és részleges regresszió révén kialakult állapotként ismertük fel, melyben egy pillanatra újra feléled az idealizált résztárgy és az örömteli részén primitív, preverbális, a paranoid-szkizoid poziciónak megfelelö élménye, s a valóság aktuális, tudatos észleletével interferálva kompromisszumképzödményt hoz létre. Swartz új szempontot vet fel, amikor a prousti idöélményt regresszív vagy közelpatológiás állapotok helyett a személyiségfejlödést, az önmegvalósitást elösegíto" transzcendens élményekként értelmezi, melyek lehetövé teszik, hogy egy másfajta tapasztalás szintjére lépve újszerü összefüggéseket tárjunk fel a világról és önmagunkról. Noha az elemzésekhez helyenként kritikai észrevételeket is füzünk, nem vitás, hogy mindegyik releváns szempontokat tár fel az énélmény és az emlékezet összefüggéseiről.
\end{abstract}

Kulcsszavak: Proust, önkéntelen emlékezet, self, nárcizmus, regresszív állapotok, transzcendens élmény 


\section{BEVEZETÉS, AZ ÍRÓ ÉS MÜVE}

Bizonyos szempontból a pszichológia és a művészetek az emberi dolgok megismerésének egymást kiegészítő eszközei. Eltérő módon bár, de mindkét megközelítés segítségével emberi élményminőségek mélyebb megértéséhez juthatunk el. Ezért mondhatjuk, hogy a művészi alkotások pszichológiai elemzése nem öncélú foglalatosság, amennyiben őszinte megismerési vágy és nem intellektualizálási kényszer vezérli. Ezenfelül a művészettől kölcsönzött példák igen alkalmasak arra, hogy egy-egy pszichológiai koncepciót érzékletessé és érthetővé tegyenek az érdeklődő laikusok számára is, ezáltal elősegítve a pszichológia által feltárt tudás beáramlását a művelt köztudatba. Az irodalomnak minden más művészetnél nagyobb hagyományai vannak e téren, de hasonló lehetőségekkel kecsegtetnek a képzőművészetek és a film is. ${ }^{1}$

Marcel Proust „Az eltűnt idő nyomában” című regényciklusa kapcsán első megközelítésben is rengeteg pszichológiai természetű asszociáció merül fel, ám jelen dolgozatban célzottan a mủ fö témáját képező prousti időélmény mélylélektani hátterének elemzésére összpontosítunk.

Először azonban lássunk néhány alapvető tényt a szerzőről és alkotásáról. ${ }^{2}$ Proust 1871-ben született Auteuilben egy híres orvosprofesszor, Adrian Proust és egy jómódú bankárcsaládból származó asszony, Jeanne Clémence Weil első gyermekeként. Gyenge és betegeskedő természete miatt egészen kicsi korától kivételezett bánásmódban részesült, s miközben a legigényesebb szellemi és társasági nevelést kapta, gyakorlatilag a széltől is óvták. Kilencéves korától az idő előrehaladtával egyre súlyosbodó gyógyíthatatlan asztma gyötörte, a tanulással azonban nem hagyott fel. Egyetemi diplomát is szerez, de a szokványos értelemben vett hivatást sohasem választ. Beteges érzékenysége miatt nem válthatja valóra szülei elképzeléseit, akik diplomáciai pályára szánták őt. Ehelyett az ifjú a nagyvilági szalonéletbe sodródik. Írói tehetségét estélyekről szóló beszámolókra, s a szalondámák túlzó portréira fecsérli, melyeket a századvégi nagyvilági lapok, a Le Figaro és a Le Gaulois közöltek. A léha szalonélet s az utazgatások közepette is írogat, munkái azonban töredékesek, befejezetlenek maradnak vagy nem emelkednek túl az ügyes mủkedvelő szintjén. Azután 1903-ban elveszíti apját, majd rá két évre édesanyját is. A tiszteletre méltó orvostanár apától - kinek temetésén a köztársasági elnök is megjelent - a gyenge és beteges fiú mindig is távol állt egy kissé, az anya halála azonban porig sújtotta. Proust apátiába esett és hónapokat töltött egy szanatóriumban. Életrajzírói egybehangzó állítása szerint anyja halálát követően fogott hozzá fő művéhez, melyen egészen haláláig, 1922-ig (azaz 17 éven át) dolgo-

\footnotetext{
1 LEVIN (1996) például beszámol olyan kísérletekről, melyekben vegyesen pszichoanalitikusokból és laikusokból álló csoportok közösen néztek és elemeztek mozifilmeket. Úgy tűnt, hogy ezáltal sikerült szórakoztató módon élményközelbe hozni a gyakran furcsán, sőt ijesztően csengő pszichoanalitikus fogalmakat, s a résztvevők úgy érezték, hogy mind önmagukkal, mind a filmekkel kapcsolatban új felismerésekhez jutottak. Emellett nem elhanyagolható szempont, hogy igen élvezték az üléseket.

${ }^{2}$ Az élettörténeti adatok tekintetében GYERGYAI (1983a-b); MAUROIS (1976); illetve RÉz (1961) munkáira támaszkodtunk.
} 
zott. A hét kötetből álló, több ezer oldalas, monumentális alkotás ${ }^{3}$ nyilvánvalóan önéletrajzi ihletettségű. Túlnyomórészt egyes szám első személyben beszéli el egy beteges gyermek „szalonhívő”, becsvágyó és naiv ifjúvá válását, szerelmeit és szükségszerủ csalódásait, majd végül megharcolt művészi krédóval rendelkező, az idő pusztító hatalmára és saját írói küldetésére rádöbbenő alkotóvá érését.

Mindezt jellegzetes, megkapó, azonnal felismerhető stílusban. A szokványos regényformához képest első pillantásra az epizódokat szervező cselekmény látszólagos hiánya és a jelentéktelennek tűnő részleteknél való hosszas időzés szembetűnő. (Proust talán minden író közül leginkább ínyence a szemlélődésnek.) A regényciklus kötetei során megismerkedünk Proust életének helyszíneivel, benyomásaival, illataival, ízeivel, s a főbb szereplőkkel, akik több valóságos figura szintéziséből születtek. A gazdag, művelt és érzékeny, ám terméketlen életet élő Swann a kezdetben tekintélyes nemes úrként megjelenő, ám később visszataszító perverz valójában is megmutatkozó Charlus báró a messziről csodált, majd később kétségbeejtően felszínesként megismert Guermantes hercegnő és családja legalább annyira jellemzőek az akkori francia társadalomra, mint Proust belső világára. Az estélyek, tengerparti nyaralások és a szerencsétlen szerelmi afférok költői leírását meg-megszakítja az író keserves küzdelme saját mủvészi képességeit illetően. Az utolsó, hetedik kötetben, mely a „Megtalált idő” címet viseli, Proust még egyszer összegyüjti regénye fő alakjait a Guermantes-udvarban. Rajtuk és önmagán felismerve az idő romboló hatását egy kiváltságos pillanatban döbben rá saját írói küldetésére: megtalálni és megörökíteni a dolgok és az emberek igazi, állandó, az idő múlásától független sajátosságait, melyeket a folyamatos változás illúziója elrejt. Az eltorzult arcok, elporladt képek, megváltozott jellemek, elmúlt szerelmek és elillant ízek romjai alól előásni az állandó igazságoknak és esszenciáknak az idő sava által oldhatatlan aranyát. Leleplezni az Időt, mely elkápráztat az állandó változás hazugságával, és felmutatni a mélyben rejlő állandóságot.

Proust gigászi munkájának eszköze az önkéntelen emlékezet, melyben egy hang, egy íz, egy szín vagy egy mozdulat egycsapásra egy teljes korábbi élménykontextust idéz fel, a hozzá tartozó énállapottal együtt, s az elbeszélő a jelen pillanattal egyidejűleg a korábbi élményt is átéli. Valami, amit az idő rég elmosni látszott, változatlan formájában újra megjelenik. Az önkéntelen emlékezés váratlan, kiváltságos pillanatait emellett mindig különleges örömérzet kíséri. A múlt egy darabkája, s egy régi énállapot újra megtaláltatik, újra élményvalósággá válik, a közben eltelt idővel dacolva.

Megragadható-e ez az élmény pszichológiailag? Megfejthetjük-e lehetséges jelentését, okait vagy célját a szerző lelki életének dinamikájában? Ezekre a kérdésekre keresünk választ a dolgozatban. Előbb azonban lássuk, konkrétan hogyan jelenik meg az önkéntelen emlékezés révén megtapasztalt sajátos prousti időélmény a regényben.

\footnotetext{
3 Teljes és hiteles magyar nyelvủ fordítás e dolgozat megírásakor csupán a regényciklus első négy kötetéről áll rendelkezésre (Proust, 1983a; ill. Proust, 1995). Az utolsó három kötetből részleges fordítások olvashatók az alábbi forrásokban: Proust (1982); Proust (1983b); BeckeTt (1988); VALACZKa (1995); RÉz (1961); MAURois (1976); GyERGYAi (1983a-b).
} 


\section{PÉLDÁK AZ ELTŰNŐ ÉS ELŐTŰNŐ IDŐRE}

A híres madeleine-epizód az, melyet a Proustról értekező tanulmányok mindenekelőtt idézni szoktak. Itt jelenik meg először a regényben az önkéntelen emlékezet, s az általa kiváltott sajátos prousti időélmény, talán minden továbbinál érzékletesebb és mélyebb leírásban; ezért ezt a részletet csak a legszükségesebb rövidítéseket eszközölve idézzük:

„Évek múltak már el azóta, hogy Combray-ból mindaz, ami nem volt az én esti lefekvésem díszlete és drámája, nem is létezett már számomra, amikor egy téli napon, hogy hazaértem a városból, anyám látva, hogy didergek, ajánlotta, hogy szokásom ellenére igyak egy kevéske teát. Először nem akartam inni, de aztán, nem tudom, hogy miért, mégis meggondoltam magam. A tea mellé anyám egy kis madeleine-nek nevezett süteményt hozatott, amelynek kicsi, dundi formája mintha csak egy rovátkás kagylóhéjba lenne kisütve. S mindjárt, szinte gépiesen, fáradtan az egyhangú naptól s egy szomorú holnap távlatától, ajkamhoz emeltem egy kanál teát, melybe előtte már beáztattam egy darabka süteményt. De abban a pillanatban, amikor ez a korty tea a sütemény elázott morzsáival keverve, odaért az ínyemhez, megremegtem, mert úgy éreztem, hogy rendkívüli dolog történik bennem. Bűvös öröm áradt el rajtam, elszigetelt mindentől és még csak az okát sem tudtam. Azonnal közömbössé tett az élet minden fordulata iránt, a sorscsapásokat hatástalanná, az élet rövidségét egyszerű káprázattá változtatta, éppúgy, mint a szerelem, s minthogyha csak megtöltött volna valami értékes eszenciával: jobban mondva, az eszencia nem bennem volt, én voltam az. Nem éreztem többé magam közepesnek, véletlennek, halandónak. Honnan jön ez a roppant öröm? Éreztem, hogy összefügg a tea és a sütemény ízével, de hogy végtelenül több $s$ nem ugyanolyan természetű. Honnan jött? És mit jelent? Hogyan tudnám megközelíteni? ... Bizonyos, hogy az, ami így, ilyen mélyen reszket bennem, a kép lesz, a látásbeli emlék, amely ehhez az ízhez van kötve, s azt próbálja követni a tudatomig. ... S hirtelen megjelent az emlék. Ez az íz annak a darabka madeleine-nek az íze volt, amit Combray-ban, vasárnaponként (mert olyankor mise előtt sose hagytam el a házat) Léonie néném szokott adni, ha felmentem köszönni a szobájába, miután előbb beáztatta a teájába vagy a hársfateába. ... S mihelyt így sikerült felismernem ennek a teába áztatott madeleine-darabkának az ízét, amelyet nagynénémtől kaptam ... az ódon, szürke ház utcai része, ahol nagynéném szobája volt, azonnal odailleszkedett, mint egy díszlet, ahhoz a kis kerti pavilonhoz, amelyet a ház mögött szüleim számára építettek (ez volt az a csonka szárny, melyre eddig egymagában emlékeztem); s a házzal együtt maga a város, a Főtér, ahova elküldtek ebéd előtt, az utcák, ahol reggeltől estig s minden időben a házbeliek megbízásait végeztem, az utak, amerre szép időben sétálgattunk. ... ugyanígy kertünk minden virága éppúgy, mint Swannék parkjáé és a Vivonna vízirózsái és a falu lakói és apróka házaik és a templom és egész Combray és a város környéke, mindaz, ami formát nyer, mindaz, ami szilárddá válik, város és kertek így szálltak fel az én csésze teámból."

(Proust, 1983a I. 54-58.)

Ha szigorúan objektív jelenségszintű leírását akarjuk adni annak, ami a madeleinejelenetben történik, akkor annyit mondhatunk, hogy fáradt állapotban, egy 
ízinger hatására a tudatos figyelem számára váratlanul, kvázi-hallucinatorikus formában és nagyfokú örömérzet kíséretében egy teljes korábbi élménykontextus idéződik fel, amit az énélmény pozitív irányú változása is kísér. Érdemes a további példákat ilyen szemlélettel olvasni, hisz e kiváltságos pillanatok gyakori kísérő és kiváltó jelenségei képezik majd a kiindulópontot a pszichodinamikai elemzéshez. Lássunk most egy jóval későbbi példát, a Szodoma és Gomorra címủ IV. kötetből (PROUST, 1995) melyben Marcel évekkel később visszatér arra a fürdőhelyre, ahol korábban, hőn szeretett - és időközben meghalt - nagyanyjával nyaralt:

„Mindjárt az első éjjel, amikor a fáradtságtól összevissza vert a szívem, megpróbáltam úrrá lenni a fájdalmon, s lassan és óvatosan hajoltam le, hogy a cipőmet lehúzzam. Alig érintettem azonban a legfelső gombot, mellkasom kitágult, megtelt valami ismeretlen, isteni jelenléttel, zokogás tört rám, s a könnyek csak úgy patakzottak a szememből. Mert aki most segítségemre sietett, aki megváltott a lélek aszályától, nem volt más, mint az, aki évekkel azelőtt, a vész és a magány ugyanilyen pillanatában, amikor már nem voltam önmagam, belépett hozzám, s visszaadta énemet, hiszen ő is én volt, s inkább mint én magam (mivel ő volt a tartalmazó, ami több, mint a tartalom, s most ezt hozta el nekem). Emlékeimből egyszerre nagyanyám gyöngéd, aggódó és szomorú arca bukkant fel, amint oltalmazón fáradságom fölé hajol, ahogyan első érkezésünk estéjén; nagyanyám arca, de nem azé a nagyanyáé, akiért oly kevéssé bánkódtam, hogy magam is csodálkoztam és röstellkedtem rajta, s aki csak nevében volt azonos vele, hanem az én igazi nagyanyámé, akit amióta csak a Champs-Élysées-n rátört a rosszullét, most leltem fel először újra eleven valójában, egy akaratlanul kiteljesült emlékben. ... Az én, aki akkor voltam, és aki oly hosszú időre eltűnt, megint oly közel került hozzám, hogy úgy éreztem, még most is fülemben csengnek az imént kimondott szavak, s mindez mégis álom volt csupán, mint amikor a félig ébredt ember véli kéznyújtásnyi közelségből hallani tovatűnő álma neszeit."

(Proust, 1995, 182-184.)

A korábbi jelenet leírásánál kiemelt mozzanatok itt is megtalálhatók. A kimerült Marcelben a figyelem fókuszán kívül eső, ez esetben proprioceptív inger (lehajolás a cipő lehúzásához) eredményeként egy olyan, évekkel korábbi jelenet uralja el részlegesen a pszichés realitást, melyhez, úgy tűnik, az adott mozdulat az egyetlen átvezető kapocs. Az élményt itt is átszellemült örömérzet kíséri, és ismét megváltozik az énélmény ${ }^{4}$ is, pontosabban e helyütt a korábbi élményhez tartozó én lép az aktuális én helyébe.

$\mathrm{S}$ a regényben újra és újra, a legváratlanabb pillanatokban, jelentéktelennek tűnő események által kioldva beindul a „múlt visszaáradása”. Hiteles magyar fordítás híján csupán röviden utalnánk néhány ilyen fontos pillanatra az utolsó kötetből (idézi SWARTZ, 1979). Az immár középkorú Proust művészi kudarcának gondolatától gyötörve gyalogosan érkezik meg a Guermantes-udvarba. Melankolikus rágódása közepette, figyelmetlensége következtében majdnem elüti egy autó.

\footnotetext{
4 Részleges énváltásról és kvázihallucinatorikus állapotról kell beszélnünk, mivel az elbeszélő minden esetben megtartja realitásérzékét a „kiváltságos pillanatok” során, és képes többé-kevésbé józan kritikával szemlélni a benne zajló folyamatot, még ha az érzelmileg meg is indítja.
} 
Amikor félreáll, hogy utat adjon, megbotlik az egyenetlen kövezeten, s lába végül is egy olyan kövön állapodik meg, mely a szomszédos köveknél kissé mélyebben helyezkedik el. Hangulata hirtelen megváltozik. Aggodalmai és kétségei elillannak, boldogság járja át. Küszködve próbálja visszaidézni azt az elmúlt pillanatot, melyet a talaj egyenetlenségének érzete megszólított. Tudatos erőlködéssel azonban semmire sem megy, az élmény most is a múlt önkényes ajándéka, s egyszer csak a jelen pillanattal együtt újra átéli, hogy régebben, Velencében a Szent Márkszékesegyháznál állt ugyanilyen testhelyzetben. Röviddel ezután, a zenedélután szünetében meghallja, ahogy egy szolga vigyázatlanul hozzákoccint egy kanalat egy tányérhoz, s ez, az elragadtatottság második hullámát előidézve visszahozza azt a pillanatot, amikor egy korábbi napon a Párizsba tartó vonat megállt, s egy vasúti munkás a kalapácsával megkondította a kerekeket. A kendő, mellyel megtörli a száját, hirtelen felidézi Balbecbe érkezése első napjának emlékét, mivel ugyanolyan durva, merev tapintású, mint az a törölköző, melyet akkor használt.

Említettük már, hogy maga Proust az idő pusztítása, pontosabban az időnek a múlt realitásait lassanként elhamvasztó hatása elleni fegyvert látott az önkéntelen emlékezetben, mely képes a múlt megélt valóságát változatlan formában újrateremteni, akár évek múltán is.

Az idő felemészt, a tudatos emlékezet szelektál és torzít, az önkéntelen emlékezet megőriz. Ebben látja a művészet célját is az író/elbeszélő. Amint azt a regényciklus végén, megtalált esztétikai hitvallásának alapelveit fejtegetve írja: ${ }^{5}$

\begin{abstract}
„S mert a művészet pontosan az életet alkotja újra, az önmagunkban megragadott valóságok körül a költészet sajátos légköre lebeg, egy misztérium édessége, s ez nem egyéb, mint az a félhomály, amelyet megjártunk.

... Arra a következtetésre jutottam, hogy a műalkotással szemben egyáltalán nem vagyunk szabadok, s nem kényünkre-kedvünkre alkotjuk a művet, hanem, minthogy már minket megelőzőleg is létezik, s mert egyszerre szükségszerű is, meg rejtett is, fel kell fedeznünk, olyasformán, mint egy természeti törvényt. De e felfedezés, amelyet a művészet tétethetett velünk, voltaképpen nem annak felfedezése-e, aminek a legértékesebbnek kellene lennie számunkra, s ami rendszerint örökre ismeretlen marad előttünk: igazi életünk, a valóság úgy, amint átéreztük, s mely annyira különbözik attól, amit valóságnak hiszünk, hogy egyszeriben eláraszt a boldogság, mikor a véletlen elénk hozza valódi emlékét."
\end{abstract}

(Proust, 1982, 74.)

A művészet tehát ugyanazt teszi „nagyban”, amit az önkéntelen emlékezés „kicsiben” megvalósít. Igazi igazságot, valódi valóságot ment meg az idő pusztításától. Emez apró pillanatok valóságát és igazságát, amaz az egész életét.

Összefoglalásként tehát felsorolásszerủen még egyszer felidézzük az önkéntelen emlékezés pillanatainak legfontosabb jellemzőit, melyekre a következő pszichodinamikai elemzés során támaszkodunk:

\footnotetext{
5 Jelen tanulmányban nem célunk az esztétikai szempontú elemzés. Proust idevágó gondolatait is inkább azért idézzük, mert egyben művéhez, s az alkotás folyamatához való viszonyáról is árulkodnak.
} 
- Akaratlagosan szabályozhatatlan, a személy ${ }^{6}$ számára váratlanul jelenik meg.

- Valamilyen jelentéktelennek tűnő inger váltja ki, melyet a személy a felidéződő múltbeli eseményben is ugyanúgy vagy nagyon hasonlóan tapasztalt.

- Mindig komplex élmények, teljes érzékletes kontextusok visszatérésével jár.

- Érzelmileg az emelkedettség és az öröm intenzív élménye kíséri.

- Az énélmény megváltozik, gyakran az adott kontextushoz tartozó korábbi énállapot tér vissza.

Fő feladatunkhoz elérkezve felmerülhet egy kérdés: Vajon nem merészkedünk-e túlzottan ingoványos talajra, mikor nem minden spekulatív elemtől mentes pszichodinamikai elméleteket szegezünk neki egy regénynek, melynek több jogosult olvasata is létezhet, s ezek között talán maga az író sem tud dönteni?? Úgy érezzük azonban, hogy egy kérdésről a fentiek tudomásulvétele mellett is dönthetünk: Jó modelljét adja-e az adott pszichológiai elmélet az önkéntelen emlékezés, s a hozzá kapcsolódó időélmény jellegzetességeinek? Azaz: alkalmas-e a jelenség kimerítő magyarázatára, s ezáltal felvet-e további érdekes kérdéseket, juttat-e valamilyen általánosabb felismeréshez?

\section{PROUST A KOHUTI METAPSZICHOLÓGIA TÜKRÉBEN}

A prousti regényciklus legismertebb pszichológiai interpretációja Heinz KOHUT (1977) nevéhez füződik és szervesen illeszkedik a szerző által kidolgozott selfpszichológia gondolatrendszerébe (KOHUT, 1971, 1977; magyar áttekintésben KULCSÁR, 1992; FODOR, 1985).

Hartmann (idézi LUKÁCS, 1992; HAMILTON, 1996) volt az, aki elsőként választotta külön egyértelműen az énnek a kognitív működéseket és a viselkedést szervező aspektusát (az egofunkciókat), illetve az én tartalmi aspektusát (a selfet). Ezt a megkülönböztetést HAMILTON (1996, 21) úgy teszi érzékletessé, hogy rámutat: az egofunkciók bár szervezik mentális működéseinket, nem jelennek meg az élményeinkben, „az introspekció során az ego megfigyelő marad a megfigyeltben”; ezzel szemben a self az én megélhető, megtapasztalható oldalára, az énélményre utal. A kezdetben Hartmann utódának tekintett Kohut (ORNSTEIN, 1996) főként nárcisztikus személyiségzavarban szenvedő páciensekkel folytatott munkája során térképezte fel a self önálló fejlődési folyamatának dinamikai és genetikus sajátosságait.

Elmélete szerint (KOHUT, 1971, 1977) az énélmény szférájának fejlődésében a testről, az elméről, a selfről, illetve a tárgyak egyes aspektusairól való izolált töredékélmények jelentik az első állomást, ezekből épülhetnek fel később az archaikus,

\footnotetext{
${ }^{6}$ Szándékosan nem Proustra, hanem egy általános alanyra vonatkoztatva szedjük pontokba az önkéntelen emlékezés jellemző sajátosságait. Ezzel azt a véleményünket fejezzük ki, hogy Proust egy olyan emberi tapasztalatot örökített meg, mellyel mindannyian találkoztunk vagy találkozhatunk.

7 Lásd például DENNETT (1998) értekezését a szerző véleményének megbízhatatlanságáról az általa írt szöveg jelentésével kapcsolatban.
} 
ámde kohézív nárcisztikus konfigurációk (az énről alkotott nagyzásos-exhibicionisztikus képzet, a grandiózus self, és a szülő mindenhatónak és mindentudónak megélt képzete az idealizált szüló imágó). Az integrációban felbecsülhetetlenül nagy jelentősége van a szülők empatikus, örömteli visszajelzéseinek, melyek mintegy érvényesítik, visszaigazolják a kicsi létezését. A gyermek azáltal válik képessé egységes létezőként megtapasztalni önmagát, hogy szülei egységes lényként reagálnak rá. Az idealizált szülő imágó és a grandiózus self irreálisan idealizált jellege abból fakad, hogy a gyermeknek védekeznie kell az ellen az élmény ellen, amit akkor tapasztal, amikor a primer nárcizmus (a korai egységesség és tökély) állapotát az anyai gondoskodás elkerülhetetlen tökéletlenségei megzavarják. A gyermek voltaképpen helyreállítja a korábbi tökéletességélményt azáltal, hogy egyrészt kialakít önmagáról egy grandiózus képzetet, másrészt a korábban átélt feltétlen tökélyt részben a vele kapcsolatban álló szülőre ruházza. Ha azonban a szülők adekvátan viselkednek ebben a korai életszakaszban, a nárcisztikus konfigurációk fokozatosan az önbizalom, az ambíciók, illetve a tisztelet és az ideálkövetés érett formáivá alakulva épülnek be a felnőtt személyiségbe.

Láthatjuk, hogy a fejlődéssel a koherencia fokozódik, ennek megfelelően a regresszió egyre súlyosabb dezintegrációt jelent. A self potenciális fragmentációja a szorongás fó forrása a nárcisztikus jellegű zavarokban, mivel a fragmentáció az egységes énélmény elvesztésével, a pszichológiai megsemmisüléssel egyenértékü.

Kohut Proust-elemzése szempontjából különösen fontos az a gondolat, hogy a szülők tükröző megnyilvánulásainak elégtelensége gátolja a self kohéziójának kialakulását és az énélményt fragmentációra hajlamossá teszi. Maga KOHUT (1971, 118.) a következőt írja a fejlődés legkorábbi fázisáról:

„Arra a következtetésre juthatunk tehát, hogy az anya gyermekének egészleges lényére örömtelien reagálva (pl. léte és ténykedése feletti örömében nevén szólítva őt) segíti elő a megfelelő fejlődési fázisban az autoerotizmusból a nárcizmusba való átmenetet, a fragmentált self (a selfmagok) stádiumából a kohézív self stádiumába történő átlépést, azaz, az énélmény mint térben egységes és időben folytonos fizikai és mentális egység kialakulását.,

KoHut (1977) úgy vélte, hogy Proustot krónikusan fenyegette a fragmentáció veszélye, s hogy az „eltűnt idő” megszállott keresésével voltaképpen az ingatag self folytonosságát és egységét próbálta helyreállítani. Eszerint a regényciklusban található számtalan példa az elszigetelt élményrészletekkel való hosszas bíbelődésre, a gondolkodási és testi folyamatok részletes boncolgatására, valamint a helység- és személynevek etimológiáján való véget nem érő töprengésre mind-mind a fragmentáció bizonyítékai. Az önkéntelen emlékezet kiváltságos pillanatai pedig, melyben az elbeszélő két, időben nyilvánvalóan távol eső pillanatot szinte egy időben él át, mintegy bizonyítékot jelentenek folytonos, történetiséggel bíró pszichológiai létezésére. A két, egymástól évekkel elválasztott pillanattal egyszerre szembesülve felsejlik az a mindkettőben közös minőség, mely voltaképpen önmagával azonos, s melyet a hétköznapi létezésben minduntalan elveszni érez. KOHUT (1977) hangsúlyozza, hogy a selfpszichológiai terápiában a gyermekkori emlékek visszaidézése gyakran nem elsősorban a tudatossá tételt szolgálja, hanem a self kontinuitásának 
erősítését. Az egység és az önazonosság érzése azonban csak felszínesen valósítható meg a történeti pozíció felvétele által (azaz önmagunknak a múltban való felismerése és egy lehetséges jövőbe való beleképzelése révén). A mély megalapozáshoz a tükrözés, pontosabban szólva a „tükrözve levés” élménye is szükséges. KOHUT (1977) meg is kérdőjelezi Proust hősies próbálkozásának sikerességét, rámutatva, hogy noha az írás kreatív erőfeszítése éveken át „összetartotta” Proustot az addig ezt a funkciót elsősorban működtető fő self-tárgy (az anya) halála után, a regényben a fragmentáció már említett példái szüntelenül visszatérnek. Elismeri azonban, hogy Proust a nagy alkotókra jellemző módon, miközben saját művészi ambíciójának kiteljesítésén munkálkodott, akaratlanul is megörökített egy olyan pszichológiai problematikát, mely később a nyugati világ általános kortünetévé vált. Kohut ugyanis a modern mủvészetek formabontó törekvéseiben, az atonális zenében, a nyelvi formákat elvető költészetben, a széthulló vizuális és taktilis világot megjelenítő képzőművészetben egyaránt a self fragmentációjának élményét látta kifejeződni, illetve azokat a törekvéseket, melyek a fragmentumokból új struktúrákat próbálnak létrehozni. Összhangban azzal, hogy a modern ember alapkonfliktusa már nem a Freud által leírt belső harc az ösztönök és a normák között, hanem egyfajta belső hiány, mely a visszajelzést nem kapó, idealizálható figuráktól megfosztott gyermeket egy életen át elkíséri, a pszichológiában és a művészetekben egyaránt új paradigmák merültek fel. Proust korát megelőzve „dokumentálta" a fragmentált self problematikáját, s KOHUT (1977) szerint tulajdonképpen ugyanazt fejezte ki művészi eszközökkel, amit a modern selfpszichológia tudományos formulákban próbál átadni az embereknek.

Hozzátehetjük, hogy a pszichopatológiai „paradigmaváltásnak” valóban vitathatatlan jelei mutatkoznak a század második felére kikristályosodott technikai és elméleti újításokban. BÁLINT (1994) őstörés koncepciója és az illusztrálására bemutatott klinikai példái kísértetiesen emlékeztetnek a Kohut által leírt nárcisztikus állapotokra. A magyar PANETH Gábor (1985) Ödipusz mondája helyett Philoctetes történetét javasolja mint a modern emberre jellemző konfliktust pontosabban szimbolizáló mitológiai példát. Egyesek (pl. LASCH, 1978; RINSLEY, 1982) a társadalmi tényezők döntő befolyása mellett érvelnek, s a nárcizmus jelenségvilágában jártas olvasónak gyakran lehet déjà vu élménye RIESMAN (1973) híres tanulmányának olvasása közben is, melynek egyik fó témája a jóléti, fogyasztói társadalmakhoz kapcsolódó „kívülről irányított” karakter, akinek legfőbb motivációja a szociális elismerés megszerzése. Mindez azt az érdekes implikációt hordozza, hogy a társadalmi-gazdasági átalakulások, azáltal, hogy sorozatosan új és új alkalmazkodási feladatok elé állítják az embereket, s így átformálják élményvilágukat, egyaránt folytonos megújulásra késztetik a pszichológiai elméleteket és az esztétikai rendszereket.

Kohut Proust-elemzésére visszatérve: elfogadhatjuk-e tehát, hogy a regényciklus voltaképpen az író saját selfjének koherenciájáért folytatott küzdelmének története, s az élménytöredékeknél való hosszas időzés a visszatérő fragmentáció jele, míg a múlt felidézése, s a művészi alkotás oly tevékenységek, melyekkel az író az énélmény folytonosságát érzi helyreállítani? E magyarázat nagyjából minden jelenséget a helyére tesz, s Proust élettörténetére tekintve is plauzibilisnek tűnik. 
Csupán egyetlen ponton mutat más arcot a prousti „táj”, mint amit a kohuti „térkép” jelez. Kohut ugyanis hangsúlyozza, hogy a fragmentumok feléledése negatív, szorongató élmény. Ahogyan ő maga írja: „Fontos, hogy a páciens negatív kifejezéseket használ, amikor megpróbálja leírni a testi és szellemi self, illetve a selftárgy töredékeiről való élményeit." (KOHUT, 1971, 30.) Noha azt kétségtelenül el kell ismernünk, hogy Proust gyakran mintegy kívülállóként szemléli saját testi és mentális funkcióit, illetve a benne keletkező benyomásokat, észre kell vennünk azt is, hogy egyáltalán nem idegenkedik tőlük, sőt kifejezetten gyönyörködik bennük. A kohuti teória tehát nem ad magyarázatot az élménytöredékekből áradó örömérzetre, valamint arra a tényre, hogy Proust mindinkább igyekszik elmélyedni ezekben az élményekben, hogy feltárja jelentésüket, titkukat. Ellene vethetnénk e kritikai észrevételnek, hogy az író/elbeszélő ezeket az izolált élménytöredékeket nem önmagukért hajszolja, hanem azért, mert megtanulta, hogy az önkéntelen emlékezet aktusának kioldójaként szolgálhatnak, ami viszont selfjének konzisztenciájáról adhat bizonyságot. Ezt az ellenvetést két ok miatt nem tartjuk jogosnak. Egyrészt a töredékes élmények gyakran akkor is örömérzettel járnak, ha semmilyen felismerhető emlékhez nem vezetnek (azaz nem torkollnak önkéntelen emlékezeti aktusba), másrészt már a legelső epizód során, amikor Marcel felfedezi az önkéntelen emlékezést (a madeleine-jelenetben), megfigyelhető, hogy az íz izolált élménye által kiváltott túláradó öröm még azelött jelenik meg, hogy a múlt hozzákapcsolódó darabkája felidéződne (és a jelen pillanattal való szembeálításban kiemelhetné a mindkettőt megtapasztalt self folytonosságát). Marad tehát a kérdés, hogy mi teszi különös öröm forrásává ezeket az élménytöredékeket?

\section{A MÚLT MINT A TÖKÉLETES SZERETET ILLÚZIÓJÁNAK FORRÁSA}

Steven SANDS (1985) némiképp eltérő perspektívából elemzi a prousti élményvilág jelenségeit. Értelmezésében a múlt feltárása nem elsősorban a self koherenciájának helyreállítását célozza, hanem egy a múltban megtapasztalt szeretet, és az ehhez kapcsolódó pozitív selférzés ismételt felelevenítését, azaz a szélsőségesen idealizált anyával való kapcsolat élményének megőrzését. SANDS (1985) fontos életrajzi adalékként emeli ki, hogy Proust az anyja halála utáni súlyos megrázkódtatásból felépülve fogott hozzá művéhez, illetve, hogy ekkor is elsősorban éjszaka dolgozott. Ennek jelentőségét könnyebben megérthetjük azoknak a regényben található leírásoknak a fényében, melyek szerint a kis Marcelt csakis édesanyja elalvás előtti csókja szabadíthatta meg az álmatlan vergődéstől. Eszerint a lázas éjjeli alkotás, mely jórészt elmúlt események felidézéséből és aprólékos boncolgatásából áll, valójában heroikus kísérletnek tekinthető arra, hogy virtuálisan újrateremtse azt az elveszített figurát (az anyát), aki képes enyhülést adni, illetve azt a kontextust, melyben ez a figura még rendelkezésre állt. Sands gondolataiból kiindulva abban ragadható meg az önkéntelen emlékezet jelentősége, hogy egyfelől evidenciaélménnyel kísért, hiteles információt közvetít abból a múltból, mely az élő és elérhető anya központi figurája köré szerveződő aranykorként tűnik fel, másfelől feleleveníti azt a pozitív selfélményt is, mely az idealizált anyával való 
kapcsolatra épült. Fontos jellegzetesség, hogy erre a múlt felkavarásán keresztül véghezvitt restaurációra Proustnak krónikus, kielégíthetetlen szüksége volt. (Emlékezzünk rá, hogy anyja halálától saját haláláig folyamatosan dolgozott a művén.) SANDS (1985) ezt arra vezeti vissza, hogy az anya halálát az író sosem tudta adekvát gyászmunka keretében feldolgozni, mivel az anya sosem vált elkülönült és független, teljes értékű tárggyá Proust számára, hanem kohuti értelemben vett self-tárgy maradt, azaz az író mindig is saját énje részeként élte meg őt, a vele való kapcsolatot nem tudta adekvátan interiorizálni, s azokat a szabályozófunkciókat, melyeket anyja látott el az életében, sosem tudta autonóm módon, saját pszichés struktúrája segítségével múködtetni. Ebből ered az a kiszolgáltatott rászorultság, mely a veszteséget feloldhatatlanná teszi, s az írót a múltba fordulásra készteti, ahol az elveszített kapcsolat élménye még újraélhető. SANDS (1985) ugyanakkor hangsúlyozza, hogy a nárcizmusra jellemző vonások csak bizonyos megkötésekkel érvényesek Proustra. A bizonytalan önértékelés, az irigység, az idealizált hatalmasokhoz való kritikátlan dörgölőzés kétségkívül nárcisztikus jegyek, ám egyik nárcizmusteória sem engedné meg a belső érzelmi világ olyan gazdagságát, s mások empátiás megértésének azt a mélységét, mely Proustnak tagadhatatlanul sajátja. A szerző véleménye szerint vannak olyan emberek, akik, bár viselkedésükben és megfigyelhető tulajdonságaikban kimeríteni látszanak a nárcisztikus személyiségzavar kritériumait, mégsem veszítették el teljesen az empátiás megértésre és a jelentőségteli kapcsolatokra való képességet, csupán minden ilyen kapacitásukat egy belső, idealizált, féltve őrzött kapcsolatban élik ki. Ezt a belső kontaktust a külvilág hatásaitól is óvni igyekeznek, különös tekintettel azokra a valós külső tárgyakra, melyek esetleg átvehetnék e kapcsolat helyét. ${ }^{8} \mathrm{E}$ személyek eljutnak ugyan az ödipális fejlettségi szintre, itt azonban olyan súlyos csalódást vagy elszakadást élnek át, mely az életkornak megfelelő ödipális jellegű személyiségszerveződést megingatja, és a tárgykapcsolatot - elhárító céllal - a primitívebb, preödipális jelleg felé tolja, ahol az még szélsőségesen idealizált formájában létezett. SANDS (1985) elemzésében Proust számára az jelenthette ezt a traumát, amikor édesanyja határozott elutasítással és haraggal reagált a hétéves Marcel azon kétségbeesett mesterkedésére, hogy az elalvás előtti csókot mindenáron kiharcolja. Az ominózus jelenet után az apa - s ez valójában kegyelemdöfés volt - váratlan kegyet gyakorolva mégiscsak rávette a vonakodó anyát, hogy teljesítse a gyermek kérését. Proust nárcisztikus jellegű törekvései tehát ödipális elemekkel keverednek, amit tetten érhetünk az elérhetetlen dolgok utáni sóvárgás visszatérő mintájában, legyen szó rangos társaságokról, irodalmi sikerről vagy az „eltűnt idő” megtalálásáról, mely ebben az összefüggésben az elveszített anya újramegtalálását jelenti.

Proust felszíni nárcizmusa tehát elhárítás a tárgy elvesztésével szemben (melyet hétévesen, az anyja haragjával szembesülve ugyanúgy átél, mint 27 évvel később az anya halálakor), ami viszont a tárgy olyan idealizációját vonja maga után, hogy a veszteség feldolgozása lehetetlenné válik. Ezt az elveszített, idealizált szeretetet

\footnotetext{
8 SANDS (1985) véleménye szerint Stendhal osztozott Prousttal ezekben a sajátosságokban. Elemzésének második részében azzal foglalkozik, hogy miként jelenik meg a „tárgyvesztést elhárító nárcizmus" dinamikája Stendhal életében és mủveiben. Jelen dolgozatban erre a párhuzamra nem térünk ki.
} 
próbálja Proust anyja halála után megkezdett munkájában újra felidézni, megtapasztalni, azoknak a benyomásoknak a bűvöletében, melyek mind ennek az elveszített szeretetnek az ízét hordozzák (s amelyeket az önkéntelen emlékezés képes újra valóságként feltüntetni). ${ }^{9}$ Ennek azonban nagy ára van: az élő emberekkel való reális kapcsolatok lehetőségének kizárása. Az a múltbeli szeretet, mely az éltető erő egyetlen forrása az író számára, egyben el is szigeteli ôt az élettől. S míg Proust bennső relikviáit fényesítgeti, az évek szép lassan elszállnak felette, de ő a múltba meredés közepette ezt is csak homályosan érzékeli egy-egy pillanatban:

„Azóta már sok esztendő múlt el. A lépcsőháznak az a fala, ahol a gyertya visszfényét láttam, már régóta összeomlott. Bennem is sokminden összeomlott, amiről azt hittem, hogy örökké tart. ... Viszont egy kis idő óta kezdem igen jól hallani, ha jól odatartom a fülem, a magam nehezen visszatartható zokogását. ... Ez a zokogás tulajdonképpen azóta se szűnt meg soha, s most is csak azért hallom újból, mivel az élet ma már sokkal mélyebben hallgat körülöttem..."

(Proust, 1969, I. 71-72)

\section{AZ ÖNKÉNTELEN EMLÉKEZET ÉS A FEDŐEMLÉK}

Láthattuk, hogy a fenti elemzésben nagy hangsúlyt kapott az elalvás előtti csókért való harc epizódja, mint Proust személyiségfejlódését, anyjához való viszonyát döntően befolyásoló esemény, amely mint emlék valószínűleg számos egyéb analóg eseményt is képvisel. Talán nem járunk rossz úton, ha feltételezzük, hogy sűrítve szimbolizálja azt, ahogyan a kis Marcel megélte anyjával való viszonyának történetét. ${ }^{10}$

Lássuk tehát, hogyan zajlik a regényben ez a nagy jelentőségủ epizód, mely Marcel egyetlen tudatos emlékmaradványa gyermekkorából: A családi szokás szerint lefekvéskor édesanyja felmegy Marcel szobájába és csókkal köszön el tőle. Ha azonban Prousték vendéget fogadnak, akivel vacsora után még sokáig beszélgetnek a kertben, akkor a hétéves kisfiúnak nélkülöznie kell ezt a számára létfontosságú ceremóniát. Így történt ez azon a bizonyos napon is. Éppen Swannt láták

\footnotetext{
${ }^{9}$ A korai szimbiotikus kapcsolatot visszaidéző önkéntelen emlékezeti aktus kapcsolódása az elemi érzékletekhez (ízek, illatok, proprioceptív érzetek stb.) felidézheti bennünk, hogy HERMANN (1984) a korai szag-, illetve hőorientációt a differenciálatlan anya-gyermek duálunióban eredő kezdetleges tájékozódási módoknak tartotta, melyek a keresés ösztönének legkorábbi specializálódásai, így a megkapaszkodási ösztön tárgy nélkül maradásakor meginduló minden későbbi keresés legmélyebb mintái is egyben (l. erről NEMES, 1984, 1998 összefoglalóit).

${ }^{10}$ Igen relevánsnak érezzük ezzel kapcsolatban azt, amit KOHUT $(1971,53)$ a genetikusan analóg élmények teleszkopálásának nevez. Ez a fogalom arra utal, hogy a psziché az igen korai, specifikusan patogén tapasztalatokra mintegy ráfényképezi a későbbi, hasonló jellegű, noha nem feltétlenül kritikus emlékek képét. A fedőemlékektől eltérően azonban ez a folyamat nem az elhárítás eredménye (azaz nem a trauma felidézését hivatott megakadályozni), hanem éppen a psziché azon erőfeszítéséből következik, hogy a preverbális szinten tapasztalt traumát tudatosan megragadja és kifejezze. Az elalvás előtti csókért való harc epizódja feltehetően teleszkópszerűen sűríti magában Proust anyjával való kapcsolatának viszontagságait.
} 
vendégül, s a kis Proustot már hamar aludni zavarták. Ő azonban képtelen belenyugodni, hogy megfosztják az anyai csóktól, s a szakácsnéval egy könyörgő hangú levelet küld anyjának, hogy az mielőbb jöjjön fel hozzá. A reakciót már a regényből idézzük:

„Anyám nem jött, s nem kímélve az én önérzetemet csak ennyit üzent Françoisezal: »Nincsen válasz«"

(Proust, 1969, I. 66.)

A kis Marcel ezután elhatározza, hogy történjen bármi, megvárja, amíg Swann elmegy, s akkor fogja megcsókolni anyját, mikor az feljön, hogy nyugovóra térjen. Találkozásuk a következőképpen zajlik:

„Már láttam a lépcsőházban anyám gyertyájának a fényét. Aztán őt is észrevettem; azonnal felé rohantam. A legelső pillanatban csodálkozva nézett rám, nem értette, mi történt. Aztán haragossá vált az arca, egyetlen szót sem szólt hozzám, mert hisz még kisebb dologért is sokszor napokig nem beszéltek velem. ... »Takarodj, takarodj, ha mondom, legalább apád ne lássa, hogy vártál itt, mint egy őrült!« De én egyre csak ezt mondtam neki: »Ugye, bejössz hozzám még este«, rémüldözve, mikor láttam, hogy apám gyertyájának fénye már ott táncol a folyosó falán, ugyanakkor azonban zsarolásra használva a közeledését s remélve, hogy anyám engedni fog, nehogy apám a folyosón találjon és hogy majd mégiscsak így szól hozzám: »Menj a szobádba, jövök utánad « De késő volt, apám már előttünk állt. Akaratlanul ezeket a senkitől se hallott szavakat mormoltam: »Végem van!«

De nem így történt. ... egy pillanatig csodálkozva, haragosan nézett rám, majd mikor anyám mondta néki néhány zavarodott szóval, hogy mi történt, így szólt hozzá: »De hát menj vele, hisz magad mondtad, hogy úgysem tudsz aludni, maradj egy kicsit a szobájában, énnekem úgy sincs szükségem semmire.« ... Anyám ezt az éjszakát a szobámban töltötte. ... - amikor Françoise bejött s megértette, hogy valami rendkívüli dolog történt, mivel anyámat ott látta mellettem ülve, a kezemet fogva s hagyva, szemrehányás nélkül, hogy sírjak, s azt kérdezte anyámtól: »De mi van a fiatalúrral, miért sír?« - anyám azt felelte neki: »Maga se tudja, Françoise, igen ideges, szegényke; vesse csak meg a nagy ágyat, aztán mindjárt lefekhet. «Így hát a szomorúságomat most először nem nézték valami büntetendő cselekedetnek, hanem egy akaratlan betegségnek, amelyet most hivatalosan is ideges állapotnak ismertek el, s amelyért nem tartottak felelősnek; megkönnyebbülve éreztem, hogy keserű könnyeimet nem kell aggályokkal kevernem, hogy végre sírhatok büntetlenül."

(Proust, 1969, I. 69-73.)

CHANKin (1990) szerint a madeleine-epizód, mely a regényfolyam áradását megindítja, voltaképpen fedőemléknek tekinthető, mely mögött az elalvás előtti csókért való harc kudarca, majd dicstelen, vereséggel felérő sikere áll. Ez az esemény a szó pszichoanalitikus értelmében vett traumát jelentett a gyermek Proust számára, mely elfojtást tett szükségessé. Az anya iránti harag érzése és az intenzív sóvárgás hirtelen, váratlan kielégülése olyan túlingerlésnek számított, melyet már nem lehetett tudatos szinten reprezentálni. Elsősorban ezt az élményt, s a köré csoportosuló fantáziákat fedné tehát a madeleine-epizód során felmerülő emlék. 
A regény tovább szövődő szálai, a csésze teából felszálló történetek és képek pedig a fedőemlékből kiinduló szabad asszociációknak feleltethetők meg, melyek a gyermekkor feltárására irányulnak. (Tegyük hozzá - bár Chankin ezt explicite nem mondja ki -, hogy ha érvelését elfogadjuk, az önkéntelen emlékezés többi esetében is érvényesül ez a fedőemlékjelleg.) A LAPLANCHE-PONTALIs (1994) féle szótár szerint, mely a fogalom klasszikus, freudi koncepcióját tekinti át, a fedőemlék a tünethez, az elvétéshez és az álomhoz hasonlóan az elfojtott elemek és az elhárítás közötti kompromisszum terméke. Freud (idézi LAPLANCHE, PONTALIS, 1994) elsősorban az eltolás szerepét hangsúlyozza, mely révén a valóságos vagy fantázián alapuló infantilis elemek érzelmileg kevésbé terhelt emlékképek által szimbolizálódnak. CHANKIN (1990) a következő összefüggésekre mutat rá a madeleine és az elalvás előtti csók jelenete között: (1) Az önkéntelen emlékezés kiváltságos pillanatának a tudatos akarattól való függetlensége megfelel a kis Marcel tehetetlenségének betegségével és hullámzó kedélyállapotával szemben, melyet a szülők a gyermekkor ezen pontján ismernek el először nyíltan. (2) A múltbeli élmény váratlan, örömteli felbukkanása a madeleine íze nyomán analóg az apa váratlanul megértő reakciójával, mellyel az anyát a kisfiú szobájába bocsátja; azaz a tárgyak és érzetek önkényes múltfeltáró ereje megfelel az apa szeszélyes hatalmának. (3) A madeleine kezdeti elutasítását úgy tekinthetjük, mint annak ellensúlyozását, hogy az anya kezdetben megpróbálta megtagadni a csókot. (4) A múltbeli, s a jelenlegi esemény együttes megtapasztalásának időn kívüli elragadtatott pillanatai megfeleltethetők azoknak a perceknek, amikor az édesanya az egész éjszakát a gyermek Proust szobájában töltötte, s vigasztalta őt. (A hullámokban rátörő zokogás hasonló az emlékek feltörésének hullámszerűségéhez.) A madeleine hatására megjelenő emlékben Léonie néni anyahelyettes, és valószínünek tűnik, hogy a cipő kioldása nyomán felderengő nagymama is az. Proustnak el kellett fojtania ugyan az elalvás előtti csók jelenetét, de a hozzá kapcsolódó sóvárgást újraélhette a múlt emlékei utáni sóvárgásban, a belőle fakadó haragot pedig a művészi alkotás impulzusává alakíthatta. Ebben az összefüggésben Proust kutakodása a múltban annak a megértési, feldolgozási szükségletét fejezi ki, hogy tulajdonképpen mi történt vele gyermekkorában, mit jelentenek valójában a fedőemlékek. Ez pedig szorosan összekapcsolódik azzal a kérdéssel, hogy ki is ő valójában, ami a bizonytalan selférzés jelenlétére utal. Itt kapcsolódhat Chankin gondolatmenete a korábbi selfpszichológiai értelmezésekhez: a fedőemlékek feloldása mélyebb szinten a self koherenciáját erősítő törekvés. ${ }^{11}$

Mivel Proust elsősorban nyilvánvalóan narratív eszközökkel próbálja megoldani ezeket a feladatokat, szükséges, hogy a pszichodinamikai elemzések mellett legalább jelzésszerủen utaljunk itt azokra a modern narratív selfelméletekre is, melyek a selfet nem a narráció eredendően létező kiindulópontjaként, hanem a narráció eredményeképpen létrejövő konstrukcióként kezelik. Dennet (idézi PLÉH, 1996, 1999) szerint például mivel állandóan rá vagyunk kényszerülve, hogy élményeinkről működő értelmezéseket alkossunk, szándék- és oktulajdonítás segítsé-

\footnotetext{
${ }^{11}$ ERIKSON (1954) az álomfejtés kapcsán írja, hogy az álom és a tudatos élet közötti szakadék áthidalására vonatkozó emberi törekvés voltaképpen az identitás megszilárdításának célját szolgálja.
} 
gével mindenből koherens elbeszéléseket igyekszünk gyártani, a self pedig ezen attribúciók és értelmezések által meghatározott absztrakcióként jön létre. Helyzete hasonló a testek fizikai súlypontjáéhoz. Kiszámított, „levezetett”, önértelmezésünk és elméleteink szempontjából fontos dolog, de ugyanúgy nem tudunk rámutatni, ahogyan a testek súlypontjára sem. McADAMS (1990) elméletében az egyének identitása saját maguk számára elsősorban életük történeteként jelenik meg. Azáltal formáljuk ki identitásunkat, hogy önmagunk krónikásaként megalkotjuk saját specifikus jelentőségű történetünket, mely életünkben az egységesség és a célra irányultság érzetét biztosítja. Minden egyes életszakasz más és más aspektusból formálja történetünkként megjelenő identitásunkat. A csecsemőkori kötődés minőségétől függ például, hogy a történet alapvetően pesszimista vagy optimista hangvételben fog-e íródni; a Piaget-féle műveletek előtti szakaszban lévő gyermek tapasztalatai nyomán emocionálisan színezett képzeteket halmoz fel, melyek a történet nyersanyagául szolgálnak; általános iskolás korban a történetet szervező alapvető szándékok jellege dôl el, s így tovább az élet előrehaladtával a történet (az identitás) szilárd ideológiai kerete, jellegzetes karakterei, s a jövőben való folytatódás mikéntje is meghatározásra kerülnek. $\mathrm{E}$ folyamatban az egyén egyre inkább aktív szervező-integráló (történetalakító és -(át)értelmező) szerepet játszik, ugyanakkor determinált is, hiszen csak abból az anyagból dolgozhat, amit tapasztalata biztosít a számára. Ezekben az elméletekben tehát az énélmény és a narratívum kapcsolata megfordul. Nem az eredendően koherens self következménye a koherens narratívum (mint azt például fentebb Kohut értékelése kapcsán láthattuk), hanem a koherenssé lenni tudó narratívum adja meg a self koherenciáját. ${ }^{12}$

Véleményünk szerint azonban sem az eredeti Chankin-féle értelmezés, sem a narratív selffelfogás irányába való továbbgondolása nem ad kielégítően számot az egyes benyomásokhoz, s különösen az önkéntelen emlékezet pillanataihoz elválaszthatatlanul kötődő felfokozott örömérzetről, mely független mindenfajta belátástól és koherenciateremtő jelentőségtől, és láthattuk már, hogy a self kontinuitásáról nyert bizonyság kohuti gondolatával is csak részlegesen magyarázható. SANDS (1985) korábban ismertetett elemzése ad egyfajta kiegészítő magyarázatot erre az örömérzetre, amikor azt mondja, hogy a prousti elragadtatás pillanataiban egy idealizált s elveszített szeretetkapcsolat elevenedik fel újra, a hozzá tartozó kontextuális elemekkel és énállapottal együtt. Ezzel a témával kapcsolatban különösen releváns összefüggésekre térünk ki a következő fejezetben.

\footnotetext{
${ }^{12}$ Kézenfekvő, hogy ez a folyamat az önéletrajzi emlékezés közvetítésével zajlik. BARCLAY-SMITH (1992) modellje szerint például az önéletrajzi emlékek egy rekonstruktív folyamatban alakulnak ki és többféle pszichoszociális cél szolgálatában állnak. Az érzelmi és értelmi koherencia megteremtésén túl arra is alkalmasak, hogy létrehozzák az intimitás érzését a társas közegben, illetve hogy fokozott szorongás esetén megnyugvást biztosítsanak. NEISSER (1992) egy speciális önéletrajzi emléktípust, a villanófényemlékeket elemezve úgy érvel, hogy ezek a jelentős (sokszor közéleti, történelmi) események nyomán fennmaradó rendkívül élénk és megtévesztően pontosnak tűnő, részletes emléknyomok narratív magaslati pontokként szolgálnak az egyének számára, melyek segítségével saját életükről szőtt történetüket a „világ folyásáról”, azaz a történelem, a közügyek menetéről alkotott narratívummal integrálják. A vakuemlékek olyan eseményeket őriznek, melyek segítenek elhelyezni saját kis történetünket a történelemben. Ezen koncepciók Prousttal és művével kapcsolatos mondanivalója természetesen külön tanulmányok tárgyát képezhetné. Célunk itt csupán kapcsolódási pontok jelzése volt.
} 


\section{6. ÉLMÉNYSZIGETEK, ÉNFEJLŐDÉS, ÖNKÉNTELEN EMLÉKEZET}

Bár az általunk áttekintett irodalomban nem találtunk olyan munkát, mely a prousti időélményt kapcsolatba hozta volna Melanie Klein elméletével, a Kleinféle modell olyannyira alkalmasnak túnik a prousti jelenségek magyarázatára, hogy meg kell próbálkoznunk egy ilyen elemzéssel.

A pszichológiai fejlődés kleini modelljének a későbbi elemzés szempontjából releváns alapgondolatait KULCSÁr (1996), SEGAL (1997), illetve FLASKAY (1983) alapján tekintjük át. Melanie Klein szerint a kora gyermekkori fejlődésben két alapvető élménymód különböztethető meg, melyeket a tárgykapcsolatok jellege, a szorongás meghatározó típusa és az uralkodó elhárító mechanizmus definiál. Ezek az alapképletek egyes életkorokban kizárólagosak, máskor háttérbe szorulnak, ám bizonyos mértékig az egész élet során jelen vannak. A kezdetben domináns tapasztalati konfiguráció, melyet Klein paranoid-szkizoid pozíciónak nevez, már a megszületéssel jelen van, mivel az újszülöttnek már ekkor rendelkezésére áll egyfajta primitív én, mely képes megélni a szorongást, és kivédésére primitív elhárító mechanizmusokat mozgósítani. A legkorábbi élményeket inkább az ösztönök mentális származékaiként jelentkező fantáziák kivetülése határozza meg, és nem az éretlen szubjektummal érintkező valóság tényleges sajátosságai. A ,jó tárgyat” (mely ekkor még nem az anya, csupán az anyamell) a libidó kivetülése hozza létre, s az anyával kapcsolatos valóságos pozitív élmények erősítik meg. A „rossz anyamellet" a halálösztön kivetülése teremti meg, s az anyától elszenvedett reális frusztrációk erősítik. A korai fejlődés kulcskérdése a csecsemő agressziójának és szorongásának sorsa, melyek kedvezőtlen esetben megzavarhatják azt az integrációs folyamatot, mely az idegrendszer érésével összefüggésben fejlettebb pszichológiai szerveződéshez vezethetne. A paranoid-szkizoid pozícióban ugyanis a csecsemőnek még sem önmagáról, sem a vele kapcsolatban álló tárgyakról nincs egységes és idői konzisztenciával bíró élménye. Primitív pillanatnyi ének kapcsolódnak pillanatnyi résztárgyakhoz. KULCSÁR (1996) Ogden nyomán elemezve a kleini fejlődéselméletet rámutat, hogy a pozíció egyik meghatározó vonása az idői folytonossággal rendelkező értelmező szubjektum hiánya, mely képes lenne az átélt élményeket egy tudatos metaszinten reflektálni. Ahogyan KUlcSár (1996, 25) Ogdent idézve írja:

„... a korai kogníció konkrét. A nem-reflektív selfnek olyan verbális állítások (és élmények) felelnek meg, mint »meleg van« (annak megélése helyett, hogy: »tudatában vagyok annak, hogy melegem van«).”

A paranoid-szkizoid pozíciót tehát az egységes és tudatos énélmény hiánya miatt konkrét kogníció, a történeti emlékezet fejletlensége miatt izolált „élményszigetek", s a hasítás miatt szélsőséges érzelmi állapotok jellemzik. Az idegrendszeri érés és a környezet megfelelő reakcióinak jótékony összjátéka révén a 3. hónap után kerül túlsúlyba a depresszív élménymód, melynek specifikusan új teljesítménye, hogy a csecsemő fokozatosan képessé válik önmagát, illetve a tárgyat olyan egységes és folytonos létezőként percipiálni, mely pozitív és negatív érzéseknek 
egyaránt forrása lehet. Ez következményszerúen vonja maga után az ambivalenciát és a bűntudatot, mely abból ered, hogy a gyermek megéli: az a tárgy, melyre destruktív impulzusai irányulnak, azonos azzal, amelyet szeret. A szorongás, hogy saját agressziója tönkreteheti, dezintegrálhatja a szeretett tárgyat, olyan törekvésekhez vezet, melyek e tárgynak a belső élmények világában való helyreállítását és megőrzését célozzák. Túlzottan nagyfokú szorongás esetén ez történhet a korábbi pozícióra jellemző primitív elhárítási módok súlyosan valóságtorzító feléledésével, melyek ebben az esetben specifikusan a büntudati szorongás ellen irányulnak. Adekvát formájában azonban a helyreállítás az énfejlődés strukturáló tényezője, mivel általa az én biztosan introjektálható, megnyugtató tárgyhoz jut, mellyel azonosulhat. A stabilan belsővé tett jó tárgyak teszik lehetővé a depresszív pozíció meghaladását.

A depresszív pozíció számunkra különösen fontos aspektusa, hogy ebben az élményképletben élményeire reflektáló, azokat szubjektíve interpretáló én is jelen van, s ez felülírja a paranoid-szkizoid pozícióra jellemző konkrét kogníciót. Másfelől a történeti emlékezés fejlődésével a gyermek képessé válik arra, hogy a létezést ne „élményszigetekben”, hanem folyamatos élettörténetként élje meg. Az ellentmondásos vonások szimultán megélésének képessége pedig az abszolút jó és az abszolút rossz tapasztalatainak háttérbe szorulását eredményezi komplexebb érzelmi jelentésű élmények javára.

Véleményünk szerint pontosan ezek a depresszív pozícióra jellemző sajátosságok vesznek el bizonyos mértékig a prousti önkéntelen emlékezés pillanataiban. Amikor Marcel megízleli a madeleine morzsáival kevert teát, mikor a balbeci szállodában lehajol, hogy kioldja a cipőjét, mikor a Guermantes udvarban megérzi a kövezet egyenetlenségét a lába alatt, s a többi emlékezetes jelenetben egy pillanatra elveszíti a történeti perspektívát, elveszíti az átélteket szubjektíve interpretáló ént, és konkrétan, érzékletes formában, szélsőségesen pozitív érzelmi színezettel (,abszolút jóként”) átéli a múltból felmerülő élményszigetet. Emlékezzünk rá továbbá, hogy az önkéntelen emlékezés általában olyankor történt meg Marcellel, amikor valamilyen okból rossz közérzet vagy fáradtság vett erőt rajta. Az érett én ezekben az esetekben meggyengül, s a regresszió iránti fokozott készenléti állapot alakul ki. A regresszív mozgás révén pedig a jelen pillanattal egy apró érzékletes sajátosságában osztozó korábbi esemény a már meghaladott élménymóddal kerül megtapasztalásra. Amikor az önkéntelen emlékezésben egy pillanatra részlegesen visszatér a konkrét kogníció, Proust újra megtapasztalja, mit jelent kizárólag közvetlenül érzékelhető vonatkozásai révén megélni egy helyzetet. Az ezt kísérő túláradó öröm pedig ebben az értelmezési keretben annak következménye lenne, hogy a regresszív állapotban a reflektív funkció és a történeti perspektíva elvesztése mellett visszatér a hasítás, s az elbeszélő a felmerülő élményt „tökéletesen jónak” éli meg. Ebből a szempontból nézve Proust teljes elmélete, mely szerint az önkéntelen emlékezet a végső igazság forrása, a dolgok állandó, igazi természetét feltáró élmény nem más, mint kísérlet arra, hogy a maga számára racionalizálja a múlt pillanatainak felmerülését kísérő túláradó boldogságélményt. Ennek a boldogságnak a valódi forrása azonban (a kleini pszichológia alapján értelmezve) az a korai élmény, amelyben a tökéletesen boldog és szeretetteljes részén az idealizált, 
maximálisan kielégítő résztárggyal állt kapcsolatban, s amely a regresszióban átmenetileg és részlegesen ismét dominálni kezd.

Mivel a regresszió nem teljes, nem jön létre a pszichés realitást tökéletesen eluraló hallucináció. A múltból megdöbbentő élességgel felmerülő, örömöt hozó képek valószínűleg félúton vannak a korai, idealizált tárggyal való kapcsolat élménye, s a jelen pillanatról alkotott adekvát, tudatos észlelet között. Eszünkbe juthat itt FrEud (1992) klasszikus leírása arról, hogy az infantilis, elfojtott vágy a friss, nappali élménymaradványokat megdolgozva hogyan hozza létre a manifeszt álmot. Nyomában Hollós (1933) az álom és a pszichotikus hallucinációk közös alapmechanizmusát feltételezi. Nevezetesen: az infantilis fokra regrediált én régi vágyképzetei is felélednek, ezért a zavaró ingereket, melyek őt a valóságba visszahozni igyekeznek, e régi vágyképzeteknek megfelelően hallucinatorikusan átdolgozza, s ezzel őrzi regresszív pozícióját. Hollós (1933) szerint az alvás és a különféle pszichózisok egy kontinuum mentén helyezhetők el a regresszió kiterjedtsége szerint, mellyel egyenes arányban nő a hallucináció dominanciája az adekvát, aktuális észlelet felett. Az alvás, illetve a delíriumos állapot során az én regressziója teljes, a személy valóságként érzékeli hallucinációját. A kontinuum másik végpontján, a paranoiában az én regressziója csupán részleges. A paranoiásnak a maga hallucinációja idegen, próbál is rá magyarázatot találni énjének azzal a részével, mely az aktuális valósággal kapcsolatban maradt.

Valószínűnek tűnik, hogy a fentiekhez hasonlóan, bár jóval enyhébb fokon, a prousti önkéntelen emlékezés során a hallucinációra emlékeztető élénkséggel felmerülő emlék is kompromisszum a paranoid-szkizoid pozíciónak megfelelő tökéletesen jó tárgykapcsolat primitív élménye és az aktuális szituáció valósághủ észlelete között.

Zárásként egy olyan koncepciót mutatunk be, mely a prousti idóélmény jelenségét nem regresszív vagy patológiás állapotokkal hozza kapcsolatba, hanem az önmegvalósítás, a determinációk meghaladásának humán potenciáljával.

\section{AZ ÖNKÉNTELEN EMLÉKEZÉS MINT AZ ÖNMEGVALÓSÍTÁS ÚTJA}

SWARTZ (1978) tanulmánya abból a prousti gondolatból indul ki, hogy valódi vagy tartós énünk ${ }^{13}$ tulajdonképpen a dolgok igazi valója iránti érzékenységünkkel azonos. E valódi ént azonban szüntelenül háttérbe szorítja a dolgok múlandó és esetleges sajátosságaira reagáló ideiglenes ének sorozata. Ezeket az ideiglenes éneket a szokás hívja életre, mert lehetővé teszik, hogy az egyén a legcélszerủbben és leggazdaságosabban alkalmazkodhasson az egyes élethelyzetekhez. A takarékos célszerüség szüli az átmeneti éneket, s a szokás tartja életben. Ez a gazdaságosság és praktikusság azonban szükségszerűen egyoldalúsághoz vezet az egyén részéről, s az életszituációk redukált, pontatlan észleléséhez. A szokás tehát biztonságot ad, de beszúkít. Energiát takarít meg számunkra, de bizonyos értelemben szegényeb-

\footnotetext{
${ }^{13}$ Swartz az „én” (az eredeti szövegben „self”) szót nem tárgykapcsolati, hanem általános értelemben használja.
} 
bé tesz. A szokás maximalizálja a siker valószínűségét várhatóan hosszabban fennálló körülmények között. Nélküle szüntelenül a bizonytalansággal kellene harcolnunk. Eszünkbe juthat ezen a ponton SIMON (1982) elmélete az emberi gondolkodás korlátozott racionalitásárol. Ennek lényege, hogy mivel az ember kognitív kapacitását meghaladja egyes élethelyzeteinek pontos, minden tényezőt figyelembe vevő racionális modellálása, inkább az előzetes tapasztalatai alapján kialakított, többé-kevésbé elnagyolt sémák alapján tájékozódik a helyzetekben. E korlátozottan racionális sémák, akárcsak a szokások, akkor kényszerülnek változásra, ha a tapasztalat visszajelzést szolgáltat arról, hogy már nem alkalmasak a valóság kezelésére. Szokások együttesének eltűnésével mindig „meghal” egy átmeneti én is, ám az ideiglenes ének sorozata mögött, mintegy mélyebb alapzatként mindig ott áll a változatlan, tartós én, mely őrzi képességünket a dolgok esetleges vonatkozásokon túlmutató lényegének meglátására. Láthattuk már, hogy Proust a művészet célját is ennek az érzékenységnek a felélesztésében, s az általa megragadott igazságok kifejezésében látta. Az önkéntelen emlékezés a következőképpen segít hozzá ehhez: Amikor egy periferiális érzet nyomán felidéződik egy komplex múltbeli élmény, magával húzva a hozzá tartozó énállapotot (azaz, az akkori átmeneti ént), és ezt a jelenbeli élménnyel egyidejüleg éljük át, akkor voltaképpen az történik, hogy a jelenlegi kontextus és egy időben távoli kontextus egymásra vetülve a dolgok állandó vonásait, legmélyebb sajáttermészetét emeli ki, míg a régi én és az aktuális én egymásra vetülése a valódi, tartós ént hívja életre. Ezáltal lehetővé válik, hogy legalapvetőbb érzékenységünk megnyíljon a dolgok önmagában vett realitása felé.

A szerző az önkéntelen emlékezés idő felett álló pillanatait a transzcendens létmód példájának tekinti. Ezt a fogalmat egy másik munkájában (SWARTZ, 1979) fejti ki. Eszerint a világban való létezésnek alapvetően két módja van: a részleges (particulate) és a transzcendens létmód. A részleges (mindennapi) létmódban a dolgokhoz mint specifikus, egyedi entitásokhoz közelítünk. A tárgyakhoz való viszonyulásunknak ezen a szintjén a minőségeket és állapotokat a dolgokba lokalizáljuk, s csupán az adott dolog tulajdonságaiként ismerjük fel őket. Ezzel szemben a transzcendens létmódban nem egyes tárgyak képezik viszonyulásunk célját, hanem maguk a minőségek és állapotok (pl. ritmus, intenzitás, hőmérséklet... stb.), melyek a tárgyakat jellemzik, s melyekben más tárgyakkal osztoznak. A praktikus szempontok, az emberi szemlélet kategóriái eltűnnek, a történeti perspektíva felfüggesztődik. A transzcendens megismerés közvetlen megértést jelent, mely szükségtelenné teszi a következtetést és a bizonyítást. Ahogyan az emlékezetben az önkéntelen emlékezés felel meg a transzcendens létmódnak, s a tudatos emlékezés a részlegesnek, úgy a mozgásban a célirányos járás és a tánc képviselheti a világban való részvétel két eltérő módját. SWARTZ (1979) szerint a valódi vagy tartós énünk alapját az a biológiai kapacitásunk alkotja, mely képessé tesz arra, hogy időben, tárgyi és fogalmi kategóriák tekintetében egymástól távol eső dolgok közös sajátosságait (azaz transzcendens vonásaikat) észleljük. ${ }^{14}$ A közvetlenül tapasz-

\footnotetext{
${ }^{14}$ Swartz e filozofikus gondolatát érdemes összevetni STERN amodális percepció elképzelésével (1985; magyarul áttekinti TÉNYI, 1995; KULCSÁR, 1996). Azon empirikus fejlődéslélektani eredmények alapján, melyek szerint már az újszülöttek képesek a modalitásközi transzferre, azaz egy adott perceptuális modalitásban szerzett információ átfordítására egy másik modalitásba (pl. a bekötött
} 
talható minőségek és állapotok szintjén való észlelés egyik fő haszna, hogy általa bejáratott fogalmi kategóriáinkhoz, korlátozottan racionális sémáimkhoz és szokásainkhoz képest metaszintre léphetünk és újszerű összefüggéseket fedezhetünk fel. Módunk nyílik szokványos elfogultságainkon felülemelkedve meglátni a dolgokat és önmagunkat. ${ }^{15}$ Ezáltal a hatékonyabb újjászervezés lehetőségét kapjuk. Ezért mondja Swartz, hogy az önkéntelen emlékezés - mint transzcendens létmód - nem csupán a művészi fejlődést, hanem a személyiségfejlődést is facilitálja. Az újjászervezés önmagunk újjászervezését is jelenti. Ezekben a pillanatokban feléled alapvető érzékenységünk az önmagában szemlélt, közvetlenül érzékelhető realitás iránt, s mivel ezáltal egy „másfajta látás” képességét kapjuk ajándékba, végső soron a perspektívaváltáshoz, életünk „végtelen hurok” helyzeteiből való kilépéshez, azaz önmagunk megvalósításához kerülhetünk közelebb. Valódi énünkkel a dolgok transzcendens vonásairól szerzett tapasztalatok segítségével időleges létezésünket az általánosabb törvényszerűségek mentén kiigazíthatjuk. SWARTZ (1979) maga is felhívja a figyelmet elemzésének nyilvánvaló kapcsolatára a jungi analitikus pszichológiával. Jung elméletének azon gondolatai (SÜLE, 1996 áttekintésében), melyek szerint az emberek pszichés működéseit végső soron globálisan azonos alapminták (archetípusok) szervezik, s hogy ezekhez az alaperőkhöz, illetve vezérlő iránymutatásukhoz gyakran éppen a tudatos ego megrendülése nyomán juthatunk közelebb, nyilvánvalóan párhuzamba állítható azzal, ahogyan Proustnál a tudatos gondolkodás háttérbe szorulásakor az önkéntelen emlékezésben feltárul a hamisítatlan valóság. Az ego a szokások letéteményese. Biztosítja a realitásban való boldogulást, ám ezt többnyire bizonyos fokú egyoldalúság keretében valósítja meg, mely a személyiség potenciális lehetőségeinek, $\mathrm{s}$ az ember által megélhető élményeknek egy részét kihasználatlanul hagyja. Jungnál a tudattalan nemcsak a túlságosan ösztönközelit, az elfojtottat jelenti, hanem az emberi teljesség meg nem élt „másik felét” is. Elhanyagolt élménymódokat és képeket, melyek - mivel szintén részei az emberi élmények alapvető formakészletének és energetikai forrásának - váltakozó intenzitással a megvalósulás, a tudatosulás felé törnek folyamatos integráló és szintetizáló munkára késztetve a személyiséget. Így azonban egyben humán természetének teljesebb kibontakoztatására szorítják. Az ego „rövidlátó funkcióöröme" gátja is lehet a személyiség tágabb értelemben vett fejlődésének (azaz az individuációnak), míg akár egy pszichés betegség vagy trauma is a fejlődés forrásává válhat éppen azáltal, hogy tarthatatlanná teszi a korábbi, bizonyos

szemmel szopogatott cumit később csupán vizuális úton felismerik - MELTzOFF, BORTON, 1979), STERN (1985) feltételezi, hogy az embercsecsemő alapvető képessége érzékleteinek modalitásfüggetlen (amodális, szupramodális, absztrakt) reprezentálása minden élményre jellemző globális sajátosságok alapján mint az intenzítás vagy az idői ritmus. A szerző elméletében ez a korai integrációs teljesítmény az énélmény és a szubjektív élményvilág fejlődésének alapvető tényezője. Swartz fenti fejtegetése kapcsán releváns STERN (1985) elméletének azon gondolata is, mely szerint az élet során fokozatosan kibontakozó és tartósan koegzisztáló selférzetek egy részének megélését a verbális selférzet, az én mint tárgyiasított kognitív kategória megjelenése kimondottan nehezíti. A nyelv óriási lehetőségeket nyújt a kapcsolatok szférájában, ám a megéltnek szükségszerűen csak egy része lesz megosztható.

${ }^{15}$ Hasonló leírást találhatunk a jógik meditációjával kapcsolatban WENINGER Antal (1986) könyvében. 
mértékű egyoldalúságra épült pszichés szerveződést, és nyitottá teszi az egyént a személyes, illetve a kollektív tudattalan kompenzatorikus erői, végső soron saját ősvalója, a Selbst iránt. JUNG (1998) szerint a költői alkotás lényege e belső folyamatok általános emberi jelentőségének megragadása oly módon, hogy az az adott kor embere számára érthetővé, érzékelhetővé váljon. Az intraindividuális történés mások számára is felfogható mondanivalója a kreatív erőfeszítés révén válik kommunikálhatóvá. A művészet ezáltal a korszellemet is neveli, hiszen azokat a formákat éleszti fel és artikulálja, melyek abban nincsenek jelen, noha sajátjai az emberi természetnek. Ahogyan Jung $(1998,105)$ maga írja:

\begin{abstract}
„A művészet társadalmi jelentősége ez: szüntelenül a korszellem nevelésén munkálkodik, mert azokat a formákat idézi fel, amelyek a korszellemből leginkább hiányoznak. A művész vágya a jelen kielégítetlenségéből visszavonul, amíg a tudattalanban az ősképet meg nem találja, ami alkalmas a korszellem hiányosságainak és egyoldalúságának kompenzálására. Ez a kép megragadja, és amíg a legmélyebb tudattalanból előhozza és megközelíti a tudatot, a kép átváltozik olyanná, hogy a jelen emberének felfogóképességéhez közel kerüljön."
\end{abstract}

A prousti önkéntelen emlékezésben talán e tudattalan rétegek kompenzatorikus áramait érzi meg az elbeszélő/író, s üzenetük közkinccsé tehető formájára végül az utolsó kötetben, kiváltságos pillanatok sorozata után talál rá, amikor művészi küldetésének mibenléte tudatosan megfogalmazódik benne. Fentiek fényében SWARTZ (1978, 1979) elemzése sem összeegyeztethetetlen a korábbiakkal. Jung szellemében beláthatjuk: még ha a prousti élményvilág regresszív vagy közel patológiás élményekből táplálkozik is, nyíltan, félelem nélkül megtapasztalva őket, ezek is értékes igazságok forrásává válhatnak, melyek birtokában többé nem gondolkodhatunk ugyanúgy időről, emlékezetről és önmagunkról.

\title{
8. KITEKINTÉS - MÜALKOTÁSOK ÉS PSZICHOANALÍZIS
}

A bevezetőben a pszichológiát s a művészeteket egyaránt emberi dolgok mélyebb megértéséhez segítő eszközöknek neveztük, s abban reménykedtünk, hogy a két eszköz kombinációjával fokozottabban mélyíthetjük megértésünket. Szándékosan igyekeztünk a többféle koherens értelmezés lehetőségét hangsúlyozni. Szemléletünk meghatározásában az a háttérfeltevés játszik szerepet, hogy a híressé vált (irodalmi vagy más) műalkotások és a legbefolyásosabb pszichoanalitikus elméletek, mint a kultúrtörténet kiemelkedő szellemi teljesítményei, egyaránt éppen azáltal válhattak naggyá, hogy meg tudtak ragadni valami elég általánosan és elég jellegzetesen emberit. Művészi produktumaink és a lélek működéséről alkotott felfogásaink is beszédesen vallanak ember mivoltunk bizonyos aspektusairól. Ezért a műalkotások pszichoanalitikus értelmezésekor véleményünk szerint végső soron nem az az érdekes, hogy az elmélet segítségével milyen értelmileg felfogható magyarázatot tudunk konstruálni a mü hatására vagy keletkezésének folyamatára. Az sem önmagában lényeges, hogy egy adott mủben a lelki folyamatok megjelenési 
formája mennyiben támasztja alá ezt vagy azt a pszichoanalitikus teóriát. Az ilyen irányú vizsgálódások csupán lépcsőfokoknak tekinthetők annak a sokkal fontosabb kérdésnek a megválaszolása felé, hogy pszichoanalitikus gondolatrendszernek és müalkotásnak milyen közös mondanivalóját találhatjuk emberi természetünkre vonatkozóan. $\mathrm{Ha}$ nem elsősorban elméletek szemléltetését, igazolását vagy művek és művészek titkainak felfedését várjuk az analitikus elemzéstől, hanem ilyen közös tanulságokat keresünk, akkor felismerhetjük: nem annyira nehézségeket, hanem inkább lehetőségeket rejt magában az a tény, hogy mindkét részről (a műalkotások s az analitikus elméletrendszerek tekintetében is) van bizonyos interpretációs játékterünk.

\section{IRODALOM}

BÁLINT, M. (1994) Az őstörés. Akadémiai Kiadó, Budapest

Barclay, C. R., Thomas, S. S. (1992) Autobiographical remembering: creating personal culture. In Conway, M. A., Rubin, D. C., Spinnler, H., Wagenaar, W. A. (eds) Theoretical perspectives on autobiographical memory. 75-97. Kluwer Academic Publishers, Netherlands

Beckett, S. (1988) Proust. Európa Könyvkiadó, Budapest

Chankin, D. O. (1990) The goodnight kiss and involuntary memory in Proust's Remembrance of Things Past. Psychoanalytic Review, 3, 409-422.

DennetT, D. C. (1998) Az intencionalitás filozófiája. Osiris Kiadó, Budapest

Erikson, E. H. (1954) The dream specimen of psychoanalysis. Journal of the American Psychoanalytic Association, 2, 5-56.

FLASKAY, G. (1983) Melanie Klein elméleti és technikai újításai az analitikus pszichoterápiában. Magyar Pszichológiai Szemle, 45, 119-133.

FODOR, L. (1985) Heinz Kohut nárcizmuselmélete - Áttekintés. Pszichológia, 5, 111-145.

Freud, S. (1992) Álomfejtés. Helikon Könyvkiadó, Budapest

Gyergyai, A. (1983a) Marcel Proust. In Proust, M. Az eltúnt idő nyomában I. 5-32. Európa Könyviadó, Budapest

Gyergyai, A. (1983b) Proust múzsái. In Proust, M. Az eltünt idő nyomában II. 549-570. Európa Könyvkiadó, Budapest

Hamilton, N. G. (1996) Tárgykapcsolat-elmélet a gyakorlatban. Animula Kiadó, Budapest

Hermann, I. (1984) Az ember ősi ösztönei. Magvető, Budapest

Hollós, I. (1933) Az álom és az elmebetegségek munkája. In Lélekelemzési tanulmányok. 143-154. Magyar Pszichoanalitikus Egyesület, Somló Béla Könyvkiadó, Budapest

JUNG, C. G. (1998) Az analitikus pszichológia és a költői műalkotás közti összefüggésről. In Bókay, A., Erős, F. (szerk.) Pszichoanalizis és irodalomtudomány. 94-105. Filum Könyvkiadó, Budapest

Konut, H. (1971) The Analysis of the Self. International Universities Press, New York

KoHut, H. (1977) The Restoration of the Self. International Universities Press, New York

KulCSÁr Zs. (1992) Bevezetés a klinikai pszichológiába. In Varga Izabella (szerk.) Klinikai pszichológiai szöveggyüjtemény. 5-40. Universitas Kiadó, Budapest

Kulcsár Zs. (1996) Korai személyiségfejlődés és énfunkciók. Akadémiai Kiadó, Budapest 
Laplanche, J., Pontalis, J. B. (1994) A pszichoanalizis szótára. Akadémiai Kiadó, Budapest

LASCH, C. (1978) The Culture of Narcissism. Norton, New York

Levin, L. (1996) Analysts Meet the Community at the Movies. The American Psychoanalyst, 1, $7-11$.

LukÁcs, D. (1992) Heinz Hartmann és az én-pszichológia. In Kulcsár Zs., Lukács D., Komlósi A. (szerk.) Függés-függetlenség. 86-106. Tankönyvkiadó, Budapest

Maurois, A. (1976) Proust. Gondolat Könyvkiadó, Budapest

McAdams, D. P. (1990) Unity and purpose in human lives: The emergence of identity as a life story. In Rubin, A. I., Zucker, R. A., Emmons, R. A., Frank, S. (eds) Studying Persons and Lives. 7-52. Springer Publishing, New York

Meltzoff, A. N., Borton, W. (1979) Intermodal matching in human neonates. Nature, 282, 403-404.

NeIsser, U. (1992) Pillanatfelvételek vagy magaslati pontok? In Kónya A. (szerk.) Az emlékezés ökológiai megközelitése. 449-455. Tankönyvkiadó, Budapest

Nemes L. (1984) Hermann Imre munkássága. In Hermann, I. Az ember ősi ösztönei. 586611. Magvető Könyvkiadó, Budapest

Nemes L. (1998) Alkotó és alkotás. Animula Könyvkiadó, Budapest

Ornstein, P. H. (1996) Heinz Kohut és a Self pszichológia. Pszichoterápiás hétvége a Hidegkút Alapítvány szervezésében, 1996. április, Budapest

Paneth, G. (1985) A labirintus járataiban. Magvető Könyvkiadó, Budapest

PléH Cs. (1996) A narratívumok mint a pszichológiai koherenciateremtés eszközei. Holmi, 2, 265-282.

PLÉH Cs. (1999) Interakciós és narratív identitás. Magyar Pszichológiai Szemle, 1, 25-34.

Proust, M. (1969) Az eltünt idő nyomában. I. Európa Könyvkiadó, Budapest

Proust, M. (1982) A megtalált idő - részletek. In Sík Csaba (szerk.) Ars poeticák a XX. századból. 74-75. Gondolat Könyvkiadó, Budapest

Proust, M. (1983a) Az eltünt idő nyomában. I-III. Európa Könyvkiadó, Budapest

Proust, M. (1983b) Az eltűnt idő nyomában - részletek a regényciklusból. Nagyvilág, 4, 567-583.

Proust, M. (1995) Az eltünt idő nyomában. IV. Atlantisz Könyvkiadó, Budapest

RÉz P. (1961) Proust. Gondolat Könyvkiadó, Budapest

Riesman, D. (1973) A magányos tömeg. Közgazdasági és Jogi Könyvkiadó, Budapest

Rinsley, D. B. (1982) Borderline and Other Self Disorders. Jason Aronson, New York

SANDS, S. (1985) Narcissism as a defence against Object Loss: Stendhal and Proust. Psychoanalytic Review, 1, 105-127.

SEgAl, H. (1997) Bevezetés Melanie Klein munkásságába. Animula Könyvkiadó, Budapest

Simon, H. (1982) Korlátozott racionalitás. Közgazdasági és Jogi Könyvkiadó, Budapest

STERn, D. N. (1985) The interpersonal world of the infant. A view from psychoanalysis and developmental psychology. Basic Books, New York

SÜle, F. (1996) A Jungi mélylélektan napjainkban. GyuRó Technik Kiadó, Szokolya

Swartz, P. (1978) Marcel Proust and the Problem of Time and Self. Psychological Reports, 1, 291-297.

Swartz, P. (1979) Marcel Proust and the Transcendent Encounter. Perceptual and Motor Skills, 3, 907-916. 
TÉNYI, T. (1995) A pszichoanalitikus pszichológia új korszaka. A Self-szerveződés elmélete. Pszichoterápia, 6, 407-422.

Valaczka, A. (1995) Prousttól Marquezig - regényértelmezések. Nemzeti Tankönyvkiadó, Budapest

Weninger, A. (1986) Az idö partján. Tankönyvkiadó, Budapest

\title{
PSYCHODYNAMIC ANALYSIS OF THE PROUSTIAN TIME-EXPERIENCE
}

\author{
PINTÉR, FERENC
}

In this contribution we have tried to explain Proust's characteristic time-experience connected to the acts of involuntary memory, in the scope of different psychological theories. During moments in the depressing state of tiredness or discomfort unexpectedly an old experience comes back with shocking sharpness and a flood of joy elicited by an effect of a trivial, seemingly insignificant sensory stimulus. Proust thought that by involuntary memory he could obtain moments when past experiences revealed their truth avoiding the selection and distortion of the conscious ego and conscious memory. The writer believes that involuntary memory shows the real and permanent essence of things. According to Kohut's explanation the proustian time-experience in which the narrator feels himself in two chronologically distant moments at the same time is significant because it provides evidence about the historically continuous psychological existence of the writer, thus helps him to maintain the coherence of his weak self. Sands argues that Proust wants to regain a particular but extremely positive self-experience which belongs to the symbiotic relationship with the idealized mother, and which can be revived only by involuntary memory after the mother's death. Chankin takes the famous Madeleine-scene as a starting point and explains the involuntary memory and the association chains derived from it as an attempt to resolve the screen memory which hides the traumatic childhood. This striving is embedded in Proust's deeper endeavour to solidify his identity by exploring his real past. We have made our own effort to explain the proustian time-experience on the basis of Melanie Klein's theory. In this framework the moments of involuntary memory can be recognized as a partial and temporary regressive state in which the primitive preverbal experience of the relationship between the idealized part-object and the joyful part-self (which is a characteristic of the paranoid-schizoid position) revives for a moment and forms a compromise by interfering with the actual conscious perception of the reality. Swartz presents a new aspect since he regards the proustian involuntary remembering as a transcendent experience (instead of a regressive or near-pathological state) which advances the process of personality development and individuation by showing new relations of things and the perceiving subject from a different level of perception. While we made some critical remarks on the discussions, there is no doubt that all of them reveal relevant aspects of the relation between memory and self-experience.

Key words: $\quad$ Proust, involuntary memory, self, narcissism, regressive states, transcendent experience 